\title{
Physiological effects of lactic acid bacteria against melamine induced toxicity in female albino rats
}

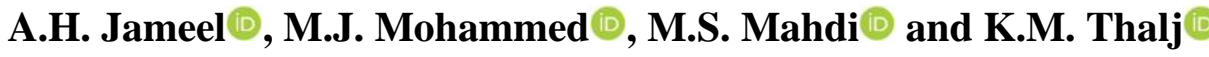 \\ Food Science Department, College of Agriculture, Tikrit University, Tikrit, Iraq
}

\begin{tabular}{l} 
Article information \\
\hline Article history: \\
Received September 15, 2019 \\
Accepted January 01, 2020 \\
Available online August 16, 2020 \\
\hline Keywords: \\
lactic acid bacteria \\
Melamine \\
Physiological parameters \\
\\
\hline Correspondence: \\
M.J. Mohammed \\
m_jamel68@ yahoo.com
\end{tabular}

\begin{abstract}
The aim of this study was to investigate the ameliorative effect of two type of lactic acid bacteria Lactobacillus casei and Lactobacillus acidophilus against melamine toxicity by some physiological indicators in mature female rats after 21 days. In this study using 35 of female mature rats and divided randomly into seven groups each group contain five animals. The results showed that melamine caused a significant decrease in the organs weights liver and spleen and increase in kidney weight with increase of melamine concentration. Also showed to decrease in value of hemoglobin, red blood cells, white blood cells, lymphocyte and platelets, while the values of granules were increasing with increase of melamine concentration as compared with control group. Also found that the addition of melamine led to increase in cholesterol, low density lipoproteins and blood glucose, while the values of triglyceride and high density lipoproteins was decreased with increase of melamine concentration. The addition of two types of lactic acid bacteria L. casei and L. acidophilus led to decreasing the negative effect of melamine on the values of all the parameters determined.
\end{abstract}

DOI: 10.33899/ijvs.2020.126183.1259, (O2021, College of Veterinary Medicine, University of Mosul.

This is an open access article under the CC BY 4.0 license (http://creativecommons.org/licenses/by/4.0/).

\section{Introduction}

Melamine chemical formula $\left[\mathrm{C}_{3} \mathrm{~N}_{3}\left(\mathrm{NH}_{3}\right)_{3}\right]$ (triazine2,4,6-triamine 1,2,5) chemical compound have white color widely diffused contained $66.7 \%$ of its weight nitrogen and melamine related to triazine family (1). Its molecular weight 126 Dalton, and considered of illegal milk additives and protein products lead to melamine toxicity in pet animals and its death in America and renal failure in children and death of high number of them in china (2). High nitrogen content of melamine and low cost make them used in many countries have low quality control to resist cheating in nutritional products and animal feed stuff (3). And the aim of this additives to increase nitrogen concentration to increase appeared protein value in nutritional products (4). The addition of one gram of melamine in one liter of milk lead to increase protein content with percentage $0.4 \%$, and the melamine can transferee to food with low concentration do not cause dangerous on humans and considered nontoxic when use in industry of cans that use to save the food that attached to food directly, and the daily limit that approved of melamine and cyanuric acid at 0.2 and $1.5 \mathrm{mg} / \mathrm{kg}$ Body weight respectively (5). Melamine considered low toxic compound if present lonely, but present of cyanuric acid that formed as byproducts of formation of melamine and usually be associated with it that increase dangerous of melamine, and make low concentration of melamine source of dangerous on human and animal health (6).

Gossner (7) mentioned that consuming of melamine of cyanuric acid lead to renal calculi formation. And cause clinical sign of vomiting, fever, hematuria, hypotension and pain at the site of kidney and not all children have renal calculi showed same clinical signs (8). The European food organization advice in European Union that all products that contain melamine more than or equal to $2.5 \mathrm{mg} / \mathrm{kg}$ should destructed (9). Also American food and drug agency (FDA) and European food organization mentioned that the daily limit approves of melamine that did not cause dangerous on 
human its $0.63 \mathrm{mg} / \mathrm{kg}$ (10). Al-Seeni (11) Recorded decrease in total leukocyte count, lymphocyte, platelets, $\mathrm{MCV}$ and MCH and increase in red blood cell count, hemoglobin, $\mathrm{MCHC}$ and monocyte with increase concentration of melamine in feed of rats. Hameed et al. (12) Mentioned to probiotic supplementation to quail ration improved the hormonal status and enhance reproduction. On other hand Carr et al. (13) mentioned this microorganism have the ability to suppress growth of wide spectrum of pathogenic bacteria, and have rule in increase production of immunoglobulin $(\operatorname{Ig} \mathrm{A})$ that have main rule in immune response of mucus membrane.

The aim of the study is to know the effect of lactobacillus bacteria in decrease negative effect of melamine in some growth, blood and lipid parameters in rats.

\section{Materials and methods}

This study was done in animal house and laboratories of Agriculture College, Tikrit University by using 35 of female mature rats obtained from college of veterinary medicine/ Mosul University and it's from Albino SpragueDawleyweanling species at age 8-9 weeks and 140-155 g body weight, divided randomly into 7 groups each group contain 5 animals and included as following: $1^{\text {st }}$ group: control, $2^{\text {nd }}$ group: animal that given melamine at dose 10 $\mathrm{mg} / \mathrm{kg}$ body weight, $3^{\text {rd }}$ group: animal that given melamine at dose $20 \mathrm{mg} / \mathrm{kg}$ body weight, $4^{\text {th }}$ group: animal that given melamine at dose $10 \mathrm{mg} / \mathrm{kg}$ body weights with $L$. casei, $5^{\text {th }}$ group: animal that given melamine at dose $20 \mathrm{mg} / \mathrm{kg}$ body weights with $L$. casei, $6^{\text {th }}$ group: animal that given melamine at dose $10 \mathrm{mg} / \mathrm{kg}$ body weights with $L$. acidophilus, $7^{\text {th }}$ group: animal that given melamine at dose $20 \mathrm{mg} / \mathrm{kg}$ body weights with $L$. acidophillus animal/day.

Lactic acid bacteria obtained from Gazi Culture Collection (GCC) Gazi University/Ankara. Melamine was obtained from Chemicals Ltd (Poole, UK). The melamine given to animals after mixing with sterile water (14) and after dissolve the concentration that mentioned in groups above. And addition of bacterial suspension of lactobacillus of each type L. casei and L. acidophillus with drinking water at number $1.5 \times 10^{8}$ colony $/ \mathrm{ml}$ of peptone water depending on Macfarland solution. The beginning weight recorded after one day of feeding animal lonely and the temperature was $20-25^{\circ} \mathrm{C}$ and light period more than 12 hours a day, and feed ad libitum and prepared according to (15) throughout period of experiment that extended for 21 days. After ending of period of experiment directly the animals fasted for 20 hours the animals anesthetized by using chloroform, anatomized to do the tests, the blood collected at $8-10 \mathrm{ml}$ at two groups on contain anticoagulant Ethylene diamine tetra acetic acid (EDTA) to do blood tests the other tubes without anticoagulant that centrifuged by using
Centrifuge at 3000 round/ minute for 15 minute to obtained the serum that stored at temperature $-20{ }^{\circ} \mathrm{C}$ until analysis, Moreover, it has been taking the weights of internal organs, which included the liver, spleen and kidney by using a sensitive balance (11).

Blood that collected by tube with anticoagulant EDTA used for measuring the red blood cells count (RBC) $\left(10^{6} / \mathrm{mm}^{3}\right)$, total leukocyte count $\left(10^{6} / \mathrm{mm}^{3}\right)$, hemoglobin concentration, platelets, granulocytes and lymphocyte by using complete blood picture system.

The serum was used for measuring Glucose, total cholesterol, triglycerides, high density lipoprotein (HDL) and low density lipoprotein (LDL) (mg $\backslash 100 \mathrm{ml})$ according to (16) by using Biolabo France kit and the analysis done by using Japanese spectrophotometer type Shimadzu and according to the wave length advised by kit company of each analysis and the concentration calculated according to the equation according to the leaflet of the kit company.

\section{Statistical analysis}

The results analyzed by using Linear Model General by SAS ready program (17) to study the effect of factors according to complete random design (CRD) also Duncan test was done (18) to defining the significant differences between means of effected factors on parameters at levels $\mathrm{P}<0.05$.

\section{Results}

Table 1 showed effect of addition of melamine with two concentration 10 and $20 \mathrm{mg} / \mathrm{kg}$ with drinking water on internal organ weight of female rats, the results showed presence of significant decrease in weight of liver and spleen at level $\mathrm{P}<0.05$ for both concentrations 10 and 20 $\mathrm{mg} \mathrm{kg}$ of melamine that was at 7.81 and $7.32,1.05$ and 0.92 in compare with control group 8.89 and $1.47 \mathrm{~g}$ respectively, also presence of significant increase in weight of kidney that reached 1.78 and $1.82 \mathrm{~g}$ of both concentration in compare with control group $1.74 \mathrm{~g}$. Also noticed there are significant increases in weight of liver and spleen and decrease weight of kidney with addition of both type of lactobacillus bacteria L. casei and L. acidophilus with melamine in compare with animals groups of melamine addition lonely.

Table 2 showed effect of melamine with two concentrations 10 and $20 \mathrm{mg} / \mathrm{kg}$ with drinking water in some blood value of female rats, the results showed presence of significant decrease in leukocyte number and lymphocyte percentage at $\mathrm{P}<0.05$ for both concentrations 10 and 20 microgram/ $\mathrm{kg}$ of melamine that was 5.32 and 4.97 in compare with control group 6.53 and 73.5 respectively, also presence significant increase in monocyte percentage that reached 6.53 and 7.43 for both concentrations in compare with control group 5.62. Also noticed there are significant increases in total leukocyte 
count and percentage of lymphocyte and decrease percentage of granulocytes at the addition of both type of lactobacillus bacteria $L$. casei and $L$. acidophilus with melamine in compare with melamine lonely.

Table 3 showed effect of addition of melamine with two concentrations 10 and $20 \mathrm{mg} / \mathrm{kg}$ with drinking water on blood values of female rats, the results showed presence significant decrease number of red blood cells and hemoglobin concentration and platelets count at $\mathrm{P}<0.05$ that was the number of erythrocyte 5.96 and 4.85 and hemoglobin concentrations 11.21 and 9.44 and platelets count 317.3 and 305.2 in compare with control group 13.86, 7.97 and 341.7 respectively, also noticed significant increase number of erythrocyte and hemoglobin concentrations and platelets count at the addition of both type of lactobacillus bacteria $L$. casei and $L$. acidophilus with melamine in control with animal groups of addition of melamine lonely.

Table 1. Effect of adding two types of lactic acid bacteria and melamine effect in organs weight ( $\mathrm{g}$ ) of female rats

\begin{tabular}{lcccc}
\hline Groups & Concentration $(\mathrm{mg} / \mathrm{kg})$ & Kidney $(\mathrm{g})$ & Spleen $(\mathrm{g})$ & Liver $(\mathrm{g})$ \\
\hline G1 & 0 & $1.74 \pm 0.029^{\mathrm{d}}$ & $1.47 \pm 0.032^{\mathrm{a}}$ & $8.89 \pm 0.015^{\mathrm{a}}$ \\
G2 & 10 & $1.82 \pm 0.054^{\mathrm{b}}$ & $1.05 \pm 0.024^{\mathrm{c}}$ & $7.81 \pm 0.020^{\mathrm{c}}$ \\
G3 & 20 & $1.89 \pm 0.015^{\mathrm{a}}$ & $0.92 \pm 0.043^{\mathrm{d}}$ & $7.32 \pm 0.012^{\mathrm{d}}$ \\
G4 & 10 & $1.78 \pm 0.026^{\mathrm{c}}$ & $1.24 \pm 0.017^{\mathrm{b}}$ & $8.35 \pm 0.058^{\mathrm{b}}$ \\
G5 & 20 & $1.83 \pm 0.018^{\mathrm{b}}$ & $1.08 \pm 0.088^{\mathrm{c}}$ & $7.85 \pm 0.029^{\mathrm{c}}$ \\
G6 & 10 & $1.77 \pm 0.005^{\mathrm{c}}$ & $1.30 \pm 0.037^{\mathrm{b}}$ & $8.22 \pm 0.020^{\mathrm{b}}$ \\
G7 & 20 & $1.79 \pm 0.011^{\mathrm{c}}$ & $1.11 \pm 0.167^{\mathrm{bc}}$ & $7.91 \pm 0.085^{\mathrm{c}}$ \\
\hline
\end{tabular}

Different letters in column refer to significant differences at level $\mathrm{P}<0.05$.

Table 2: Effect of adding two type of lactic acid bacteria and melamine effect in some parameters of WBC in female rats

\begin{tabular}{lcccc}
\hline Group & Concentration $(\mathrm{mg} / \mathrm{kg})$ & WBC $\left(10^{3} / \mathrm{mm}^{3}\right)$ & Lymphocytes $(\%)$ & Granulocytes $(\%)$ \\
\hline G1 & 0 & $6.53 \pm 0.032^{\mathrm{a}}$ & $73.5 \pm 0.057^{\mathrm{a}}$ & $5.62 \pm 0.051^{\mathrm{d}}$ \\
G2 & 10 & $5.32 \pm 0.004^{\mathrm{d}}$ & $70.6 \pm 0.176^{\mathrm{c}}$ & $6.53 \pm 0.055^{\mathrm{b}}$ \\
G3 & 20 & $4.97 \pm 0.068^{\mathrm{e}}$ & $68.7 \pm 0.328^{\mathrm{e}}$ & $7.43 \pm 0.005^{\mathrm{a}}$ \\
G4 & 10 & $5.72 \pm 0.007^{\mathrm{c}}$ & $71.9 \pm 0.261^{\mathrm{b}}$ & $5.92 \pm 0.073^{\mathrm{c}}$ \\
G5 & 20 & $5.61 \pm 0.096^{\mathrm{cd}}$ & $70.8 \pm 0.196^{\mathrm{c}}$ & $6.30 \pm 0.378^{\mathrm{b}}$ \\
G6 & 10 & $5.83 \pm 0.021^{\mathrm{b}}$ & $71.6 \pm 0.140^{\mathrm{b}}$ & $5.84 \pm 0.035^{\mathrm{c}}$ \\
G7 & 20 & $5.85 \pm 0.043^{\mathrm{b}}$ & $69.9 \pm 0.043^{\mathrm{d}}$ & $6.32 \pm 0.029^{\mathrm{b}}$ \\
\hline
\end{tabular}

Different letters in column refer to significant differences at level $\mathrm{P}<0.05$.

Table 3: Effect of adding two types of lactic acid bacteria and melamine in some parameters blood in female rats

\begin{tabular}{lccccc}
\hline Groups & Concentration $(\mathrm{mg} / \mathrm{kg})$ & $\mathrm{Hb}(\mathrm{g} / \mathrm{dl})$ & $\mathrm{RBC}\left(10^{6} / \mathrm{mm}^{3}\right)$ & Platelets $\left(10^{3} / \mathrm{mm}^{3}\right)$ & $\mathrm{MCV}(\mu \mathrm{m})^{3}$ \\
\hline G1 & 0 & $12.86 \pm 0.043^{\mathrm{a}}$ & $7.27 \pm 0.034^{\mathrm{a}}$ & $341.7 \pm 0.953^{\mathrm{a}}$ & $69.8 \pm 0.503^{\mathrm{a}}$ \\
G2 & 10 & $11.21 \pm 0.006^{\mathrm{c}}$ & $5.96 \pm 0.016^{\mathrm{c}}$ & $317.3 \pm 0.266^{\mathrm{d}}$ & $67.7 \pm 0.405^{\mathrm{c}}$ \\
G3 & 20 & $9.44 \pm 0.007^{\mathrm{e}}$ & $4.85 \pm 0.037^{\mathrm{d}}$ & $305.2 \pm 0.321^{\mathrm{f}}$ & $64.9 \pm 0.841^{\mathrm{e}}$ \\
G4 & 10 & $11.92 \pm 0.032^{\mathrm{b}}$ & $6.14 \pm 0.113^{\mathrm{b}}$ & $328.6 \pm 0.761^{\mathrm{c}}$ & $68.5 \pm 0.776^{\mathrm{b}}$ \\
G5 & 20 & $10.84 \pm 0.056^{\mathrm{d}}$ & $5.64 \pm 0.102^{\mathrm{c}}$ & $321.3 \pm 0.888^{\mathrm{d}}$ & $66.1 \pm 0.581^{\mathrm{d}}$ \\
G6 & 10 & $11.86 \pm 0.045^{\mathrm{b}}$ & $6.27 \pm 0.043^{\mathrm{b}}$ & $330.2 \pm 0.712^{\mathrm{b}}$ & $68.7 \pm 0.288^{\mathrm{b}}$ \\
G7 & 20 & $10.79 \pm 0.088^{\mathrm{d}}$ & $5.72 \pm 0.002^{\mathrm{c}}$ & $323.8 \pm 1.096^{\mathrm{e}}$ & $66.3 \pm 0.123^{\mathrm{d}}$ \\
\hline
\end{tabular}

Different letters in column refer to significant differences at level $\mathrm{P}<0.05$.

Table 4 showed effect of addition of melamine with both concentrations 10 and $20 \mathrm{mg} / \mathrm{kg}$ with drinking water on lipid profile of female rats, the results showed presence of significant increase in cholesterol value and LDL and blood sugar at $\mathrm{P}<0.05$ for both concentrations 10 and 20 microgram $\backslash \mathrm{kg}$ of melamine that was cholesterol 98.76 and
102.41 and LDL 31.82 and 33.93 in compare with control group 72.43 and 19.64 respectively, also the results showed presence of significant decrease in value of triglyceride and HDL that was 73.11 and $70.58,22.65$ and 20.31 respectively in compare with control group. Also noticed there are significant decrease in cholesterol value and LDL and blood 
sugar and significant increase in value of triglyceride and $\mathrm{HDL}$ at the addition of both type of lactobacillus bacteria $L$. casei and L. acidophilus with melamine in compare with animals groups of melamine addition lonely.

Table 4: Effect of adding two types of lactic acid bacteria and melamine effect in lipid profile in female rats

\begin{tabular}{lcccccc}
\hline Groups & $\begin{array}{c}\text { Concentration } \\
(\mathrm{mg} / \mathrm{kg})\end{array}$ & $\begin{array}{c}\text { Cholesterol } \\
(\mathrm{mg} / \mathrm{dl})\end{array}$ & $\begin{array}{c}\text { TG } \\
(\mathrm{mg} / \mathrm{dl})\end{array}$ & $\begin{array}{c}\text { LDL } \\
(\mathrm{mg} / \mathrm{dl})\end{array}$ & $\begin{array}{c}\text { HDL } \\
(\mathrm{mg} / \mathrm{dl})\end{array}$ & $\begin{array}{c}\text { Glucose } \\
(\mathrm{mg} / \mathrm{dl})\end{array}$ \\
\hline G1 & 0 & $72.43 \pm 0.058^{\mathrm{e}}$ & $83.55 \pm 0.056^{\mathrm{a}}$ & $19.64 \pm 0.029^{\mathrm{d}}$ & $31.52 \pm 0.015^{\mathrm{a}}$ & $115.53 \pm 0.023^{\mathrm{d}}$ \\
G2 & 10 & $98.76 \pm 0.061^{\mathrm{b}}$ & $73.11 \pm 0.031^{\mathrm{c}}$ & $31.82 \pm 0.034^{\mathrm{b}}$ & $22.65 \pm 0.037^{\mathrm{d}}$ & $133.63 \pm 0.006^{\mathrm{b}}$ \\
G3 & 20 & $102.41 \pm 0.125^{\mathrm{a}}$ & $70.58 \pm 0.056^{\mathrm{d}}$ & $33.93 \pm 0.023^{\mathrm{a}}$ & $20.31 \pm 0.026^{\mathrm{e}}$ & $148.58 \pm 0.049^{\mathrm{a}}$ \\
G4 & 10 & $83.46 \pm 0.007^{\mathrm{d}}$ & $77.33 \pm 0.149^{\mathrm{b}}$ & $26.84 \pm 0.040^{\mathrm{c}}$ & $25.86 \pm 0.109^{\mathrm{b}}$ & $125.71 \pm 0.084^{\mathrm{c}}$ \\
G5 & 20 & $95.38 \pm 0.032^{\mathrm{c}}$ & $72.96 \pm 0.022^{\mathrm{c}}$ & $30.45 \pm 0.036^{\mathrm{b}}$ & $23.12 \pm 0.043^{\mathrm{c}}$ & $133.26 \pm 0.026^{\mathrm{b}}$ \\
G6 & 10 & $85.72 \pm 0.097^{\mathrm{d}}$ & $76.92 \pm 0.132^{\mathrm{b}}$ & $27.94 \pm 0.049^{\mathrm{c}}$ & $26.34 \pm 0.002^{\mathrm{b}}$ & $127.45 \pm 0.049^{\mathrm{c}}$ \\
G7 & 20 & $95.13 \pm 0.124^{\mathrm{c}}$ & $73.28 \pm 0.028^{\mathrm{c}}$ & $29.91 \pm 0.051^{\mathrm{b}}$ & $25.23 \pm 0.055^{\mathrm{b}}$ & $135.01 \pm 0.006^{\mathrm{b}}$ \\
\hline
\end{tabular}

Different letters in column refer to significant differences at level $\mathrm{P}<0.05$.

\section{Discussion}

The results were agreeing with the results of and also agree with the results mentioned by (19) that recorded significant decrease in weight of liver and spleen and increase weight of kidney in female rats with the addition of melamine in the feed in compare with control group. Also the results were agreeing with Son et al. (20) that mentioned to significant decrease in weight of liver and increase weight of kidney at the addition of melamine to the feed in compare with control groups. Dobson et al. (21) Mentioned to increase weight of kidneys in rats due to addition of melamine and cyanuric acid to the feed of rats. Hameed $e t$ al. (12) mentioned presence of decrease of weight of spleen at the addition of melamine to the feed of rats with concentration of $50 \mathrm{mg} / \mathrm{kg}$ body weight. Also mentioned by $(11,22)$ to presence of significant increase of kidney weight at the addition of melamine to the feed of rats due to the damage of the renal tissue and necrosis of renal tubules and dilation of Bowman's capsule and swelling of the epithelial cells of tubules (6). Also the reason of increase of kidney weight is may be due to formation of calculi in the kidney also because obstruction of tubules in the kidney that leads to renal damage and acute renal failure (23).

The results were agreeing with the results that reached by Chan and Lai (11) that mentioned presence of significant decrease in number of leukocyte and lymphocyte and presence increase of monocyte at the addition of melamine to the feed of female rats. And the results agree with the result that mentioned by Hameed et al. (12) that indicate to significant decrease in total leukocyte count and lymphocyte in elevation of monocyte value at the addition of melamine to the feed of mice in compare with control group. Also the results agree with the results of Chen et al. (22) in presence of decrease in total leukocyte count and lymphocyte at the addition of melamine to the feed of rats.

The results were agreeing with the results that reached by (24) that mentioned presence of significant decrease in number of red blood cells and hemoglobin concentration and platelets count at the addition of melamine to the feed of female rats. And agree with what mentioned by (12) that recorded significant decrease red blood cell number and hemoglobin concentration and mean corpuscular hemoglobin concentration (MCHC) and mean corpuscular volume at the addition of melamine to the feed of mice in compare with control group, because of formation insoluble compound of Melamine cyanurate during metabolism of melamine (25). Ismail and Al-Hamdani (26) showed there were significantly increase in hemoglobin concentration in three experiments, and also the packed cell volume was significantly increase in three experiments in common carp.

The consumption this toxic compound lead to loss of iron from hemoglobin molecule of blood (27) and this reason that responsible for anemia happening. And the reason of increase of number of erythrocyte and hemoglobin concentration and the platelets count due to the rule of probiotics of production of vitamin $\mathrm{B}$, also its effect by enhance immune system, and promote absorption of vitamins and minerals, and stimulate production of organic and amino acids (28). And Kim et al. (29) mentioned that lipoteichoic acid that presence in wall of lactobacillus bacteria has anti-inflammatory effect by suppuration of receptor of platelets activation, due to the rule of platelets in activation part of immune response, this explain increase its number as response of immune activation due to consumption of probiotics that mentioned by researchers as immune enhancer.

The results were agreeing with that mentioned by (19) in presence of significant increase of value of cholesterol and triglyceride at the addition of melamine to the feed. And (9) mentioned that presence of significant increase of cholesterol value at the addition of melamine and cyanuric acid to the rat feed. Also agree with (30) that mentioned that the consumption of lactobacillus bacteria by the humans as 
probiotics lead to decrease significantly total cholesterol concentration and triglyceride and low density lipoproteins LDL. Also find that number of lactobacillus type has the ability to decrease concentration of total cholesterol and triglyceride in rats $(6,31)$.

The researches mentioned to presence of many mechanisms used by lactobacillus bacteria to decrease cholesterol level in blood, include theory of enzymes by release conjugation of bile salt by Bile salt hydrolase (BSH) enzyme of probiotic, with the release of conjugation the bile salts be less soluble and absorb by intestine and this leads to execrate with feces (32). The use of cholesterol in formation of new bile acid for homogenizing leads to decrease of cholesterol in serum (33). Also suppression formation of cholesterol in liver may be occur through production of short chain fatty acids (SCFA) like propionic acid and other by types of lactobacillus bacteria or redistribution of cholesterol from plasma to the liver (34). The case of capacitation of cholesterol done be precipitation with unconjugated bile salts cause reabsorption inside the body or by suppression cholesterol forming enzyme (35), also way of converting of cholesterol to coprostanol that execrate directly in feces (36). And may the decrease of total cholesterol and triglyceride and low density lipoproteins returned to production of glucan sugar by lactobacillus bacteria that work on increase viscosity of small intestine lead to increase excretions of bile acid lead to decrease the converting of these acids to formation of cholesterol then decrease its level in blood plasma (37).

The decrease of blood sugar in control group resulted from burning of saccharide completely burn inside the body to produce energy to utilized by different activity, while the elevation in glucose sugar returned to ability of melamine to attack beta cells of pancreas that specialized by execrate insulin hormone and destruction by accumulation of free radicals that be toxic in beta cells lead to arrest the process of glucose lyses and activation process of glucose formation and glycogen lyses, and explained the ability of bacteria to decrease glucose level through delay or suppress absorption of glucose from intestine or stimulation of insulin secretion by pancreas, or through conjugation of glucan compound that produced by lactobacillus bacteria in the intestine lead to reabsorption to the blood then decrease its concentration by execration outside with feces (38).

This significant increase in concentrations of blood biochemical picture may be returned to increase nitrogen value in composition of melamine and reached $66.7 \%$, that the molecule of melamine can lysed by effect of some enzyme and increase nitrogen in blood and occur disturb in blood content equilibrium lead to physiological disturbance of cells and transmitted nutrient and increase blood viscosity caused formation of calculi in kidney and disturbance in secretory organs like liver, also hepatocyte can effected to disturbance due to lysed nitrogen more than nature demand or cells capacity (16).

The ability of types of lactobacillus in decreases the negative effect of harmful compound through its ability to conjugate the compound and removed from intestine (39).

This bacteria work as probiotics cause decrease cholesterol in blood, many studies that showed was many types of lactobacillus have the ability to decrease cholesterol, the cholesterol levels elevated in blood a result of consumption of animal fat in food and the increase its level over normal limit leads to precipitation in blood vessels and lead to obstruction, and can decrease that levels by using probiotics as lactobacillus bacteria, also its ability to metabolite saturated fatty acids and production short chain fatty acids in the intestine by its production of enzyme that lyse fat and some of them distract cholesterol and utilize them as carbon source in its metabolism, also its able to suppress formation of cholesterol in the liver (40).

\section{Conclusion}

The results of present study showed that the using of melamine produces nephrotoxicity and the potential use lactic acid bacteria considered have the ability to decrease negative effects of melamine in some growth, blood and lipid parameters in rats, and have rule in increase production of immunoglobulin.

\section{Conflict of interests}

The authors declare no conflict of interest.

\section{References}

1. Fengt W, Changyin L, Liping Y, Jianlin C, Chengyan A. Determination of melamine concentrations in dairy samples. Food Sci Technol. 2012;47:147-153. Doi: 10.1016/j.lwt.2011.12.021

2. Zhang Q, Yang G, Li J, Li W, Zhang B, Zhu W. Regulatory toxicology and pharmacology. 2011;60:144-150. Doi: 10.1016/j.yrtph

3. Wei F, Rober, L, Stacy C, Steven L, Dean H, Na L. Rapid detection of melamine in whole milk mediated by unmodified gold nanoparticles. Appl Phys Letters. 2010;96:133-702. Doi: $10.1063 / 1.3373325$

4. Xin H, Stone R. Chinese probe unmasks high-tech adulteration with melamine. Sci. 2008;322:1310-1311. Doi: 10.1126/science

5. Hau AKC, Kwan TH, Li PK. Melamine toxicity and the kidney. J Am Soc Nephrol. 2009;20:245-250. Doi: 10.1681/ASN.2008101065

6. Xie N, Cui Y, Yin YN, Zhao X, Yang JW, Wang ZG. Effect of two lactobacillus strains on lipid metabolism and intestinal microflora in rats fed a high-cholesterol diet. Sci. 2011;11:53. Doi: 10.1186/1472$\underline{6882-11-53}$

7. Gossner C, Schlundt J, Embarek PB, Hird S, Wong D, Beltran O, Teoh $\mathrm{KN}$, Tritscher A. The melamine incident: implications for international food and feed safety. Environ Health Perspect. 2009;117:1803-1808. doi: 10.1289/ehp.0900949

8. Hu P, Wang J, John G. Liver involvement in melamine-associated nephrolithiasis, Arch Iran Med. 2012;15(4):247-248. Doi: 10.012154/AIM.0015 
9. Puschner B, Poppenga RH, Lowenstine LJ. Assessment of melamine and cyanuric acid toxicity in cats. J Vet Diag Invest. 2007;19:616-624. Doi: $10.1177 / 104063870701900602$

10. Chan ZCY, Lai W. Revisiting the melamine contamination event in China: implications for ethics in food technology. Food Sci Tech. 2009;20:366-373. Doi: 10.1016/j.tifs.2009.04.005

11. Al-Seeni MN, El Rabey HA, Al-Solamy SM. The protective role of bee honey against the toxic effect of melamine in the male rat kidney. Toxicol and indust Health. 2015;1-9. Doi: $10.1177 / 07483714551765$

12. Hameed HM, Tawfeek FK, Adul-Rhaman SY. Effect of $\beta$-mannanase, lysolecithin and probiotic on some reproductive performance and hormone profile in female quail. Iraqi J Vet Sci. 2020;34(1):87-93. Doi: 10.33899/ijvs.2019.125587.1097

13. Carr FJ, Chill D, Maida N. The lactic acid bacteria: A literature survey. Crit Rev Microbiol. 2002;28(4):281-370. Doi: 10.1080/1040840291046759

14. Xiao YT, Wing TW, Chi WL, Yi W, Wai SC, Jian L, Ye L, Huihui H, Yin X, Zhen YC, Chuen-Shing M, Chau-Ming L, Yu H. Melamine impairs renal and vascular function in rats. Sci Rep. 2004;23(4):1-6. Doi: 1038/srep2804

15. Arpita P, Shreya M, Animesh S, Keshab CM, Dilip KN. Therapeutic potential of probiotic Lactobacillus plantarum $\mathrm{AD} 3$ on acetaminophen induced uremia in experimental rats. Clin Nut Exp. 2018;19:12-22. Doi: 10.1016/j.yclnex.02.002

16. Imtara H, Al-Waili N, Bakour M, Al-Waili W, Lyoussi B. Evaluation of antioxidant, diuretic, and wound healing effect of Tulkarm honey and its effect on kidney function in rats. Vet World. 2018;11(10):14911499. Doi: $10.14202 /$ vetworld

17. SAS. SAS/STAT. User's guide for personal computers institute. USA: Cary Inc, 2010. Doi: 10.1007/s00362-008-0156-x

18. Duncan DB. Multiple range and multiple F teste. Biomed.1983;11:142. Doi: $10.2307 / 3001478$

19. Chen K, Liao C, Cheng F. Evaluation of subchronic toxicity of pet food contaminated with melamine and cyanuric acid in rats. Toxicol Pathol. 2009;37:959-968. Doi: 10.1177/0192623309347910

20. Son JY, Hyung SK, Kyu HC, Byung ML, Sung KL, Hyun JL, Tae CJ. Evaluation of renal toxicity by combination exposure to melamine and cyanuric acid in male sprague- dawley rats. Toxicol Res. 2014;30(2):99-107. Doi: 10.5487/tr.2014.30.2.099

21. Dobson RL, Safa M, Mike QR, Thomas C, Timothy R, Baker AM, Brian T, Regg AS, Bigalow K, Thomas V, Andrew F, Renate R, Gary $\mathrm{O}$, Yuching S, George PD. Identification and characterization of toxicity of contaminants in pet food leading to an outbreak of renal toxicity in cats and dogs. Toxicol Sci. 2008;106(1):251-262. Doi: $10.1093 /$ toxsci/kfn160

22. Chen Y, Bang-Ping J, Chieh-Hao W, Jhaol-Huei W, Shih-Chieh C, Maw-Sheng C, Shih-Ling H, Yi-Lo L, Ter-Hsin C, Fuu-Jen T, JiunnWang L. Kidney stone distribution caused by melamine and cyanuric acid in rats. Clin Chem Acta. 2014;430:96-103. Doi: 10.1016/j.c.003

23. Kim CW, Yun JW, Bae IH, Lee JS, Kang HJ, Joo KM, Jeong HJ, Chung JH, Park YH, Lim KM. Determination of spatial distribution of melamine-cyanuric acid crystals in rat kidney tissue by histology and imaging matrix-assisted laser desorption/ionization quadrupole timeof-flight mass spectrometry. Chem Res Toxicol. 2010;23:220-227. Doi: $10.1021 / \mathrm{tx} 900354 \mathrm{z}$

24. El Rabey HA, Al-Seeni MN, Al-Solamy SM. Bees' honey protects the liver of male rats against melamine toxicity. Bio Med Res Inter. 2013:18. Doi: $10.1155 / 2013 / 786051$

25. Zheng X, Zhao A, Xie G, Chi Y, Zhao L, Li H, Wang C, Bao Y, Jia W, Luther M. Melamine-induced renal toxicity is mediated by the gut microbiota. Sci Transl Med. 2013;5:172-22. Doi: 10.1126/scitranslmed.3005114

26. Ismail RH, Al-Hamdani AH. Effect of probiotic (Poultrystar $®)$ and heat stress on some blood parameters in common carp (Cyprinus carpio L.). Iraqi J Vet Sci. 2019;33(2):221-225. Doi: 10.33899/ijvs.2019.125539.1061
27. Barber DS, Hunt JR, Ehrich MR. Metabolism, toxicokinetics and hemoglobin adduct formation in rats following subacute and subchronic acrylamide dosing. Neuro Toxicol. 2001;22:341-353. Doi: 10.1016/s0161-813x(01)00024-9

28. Gu Q, Ping L. Biosynthesis of vitamins by probiotic bacteria. Probiotics and Prebiotics in Human Nutrition and Health. 2016. Doi: $10.5772 / 63117$

29. Kim H, Jung BJ, Jeong J, Chun H, Chung DK. Lipoteichoic acid from lactobacillus plantarum inhibits the expression of platelet activating factor receptor induced by Staphylococcus aurous Lipoteichoic acid or Esherichia coli Lipopolysaccharide in Human monocyte-like cells. J Microbiol Biotechnol. 2014;24(8):1051-1058. Doi: 10.401403.03012

30. Wu Y, Zhang Q, Ren Y, Ruan Z. Effect of probiotic lactobacillus on lipidprofile: A systematic review and 30 eta-analysis of randomized controlledtrials. PloS one. 2017;12(12):1-10. Doi: 10.1371e.0178868

31. Ben SR, Trabelsi L, Hamden K, Chouayekh H, Bejar S. lactobacillus Plantarum TN8 exhibits protective effects on lipid, hepatic and renal profiles inobese rat anaerobe. 2013;23:55-61. Doi: 10.1016/j.anaerobe

32. Lambert JM, Bongers RS, de Vos M, Kleerebezem M. Functional analysis of four bile salt hydrolase and penicillin acylase family members in lactobacillus plantarum WCFS1. Appl Environ Microbiol. 2008;74:4719-4726. Doi: 10.1128/AEM.00137-08

33. Begley M, Hill C, Gahan CGM. Bile salt hydrolase activity in probiotics. Appl Environ Microbiol. 2006;72:1729-1738. Doi: 10.1128/AEM.72.3

34. Homayouni A, Payahoo L, Azizi A. Effects of probiotics on lipid profile: A review. Am J Food Technol. 2012;7(5):251-265. Doi: 10.3923/ajft.2012

35. Liong MT, Shah NP. Effect of a Lactobacillus casei symbiotic on serum lipoprotein, intestinal microflora, and organic acid in rats. J Dairy Sci. 2006;89:1390-1399. Doi: 10.3168/jds.S0022-0302(06)72207-X

36. Lye HS, Rusul G, Liong MT. Removal of cholesterol by lactobacilli via incorporation of and conversion to coprostanol. J Dairy Sci. 2010;93:1383-1392. Doi: 10.3168/jds.2009-2574

37. Higashikawa F, Noda M, Awaya T, Nomura K, Oku H, Sugiyama M. Improvement of constipation and liver function by plant derived lactic acid bacteria: A double-blind, randomized trial. Science Dived. 2009;5:1-10. Doi: $10.1016 /$ j.nut

38. Abe F, Tomoko Y, Keiji I. "afety evaluation of two probiotic bifidobacterial strains, bifidobacterium breve $\mathrm{M}-16 \mathrm{~V}$ and bifidobacterium infantis M-63, by oral toxicity tests using rats. Biosci Microflora. 2009;1(9):7-15. Doi: 10.12938/bifidus.28.7

39. Endo Y, Kimura N, Ikeda I, Fujimoto K, Kimoto H. Adsorption of bisphenol A by lactic acid bacteria, Lactococcus, strains. Appl Microbiol Biotecnol. 2006;74(1):202-207. Doi: 10.1007/s00253-0060632-y

40. Pereira DI, Gibson GR. Effects of consumption of probiotics and prebiotics on serum lipid levels in humans. Crit RevBiochem Mol Biol. 2002;37(4):259-281. Doi: 10.1080/10409230290771519
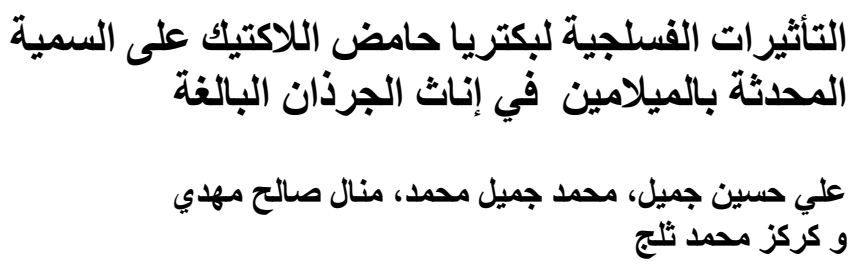

قسم علوم الأغذية، كلية الزر اعة، جامعة تكريت، تكريت، العراق الخلاصة

تهدف الدر اسة الحالية إلى معر فة تأثير نو عي بكتريا حامض اللاكتيك

Lactobacillus casei 
و الصفائح الدموية لمجاميع الجرذان، وارتفاع قيم الخلايا الحبييية مقارنة

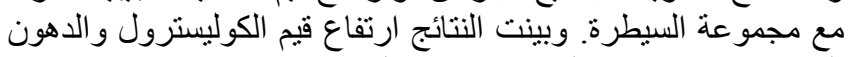

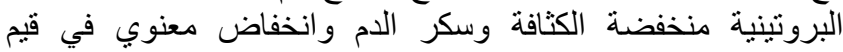

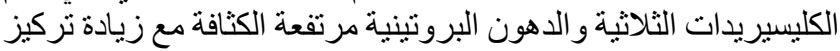

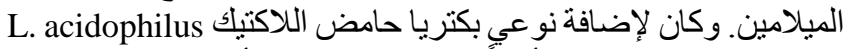

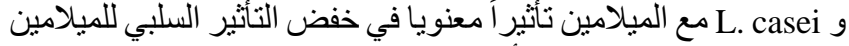
على جميع المعايير المقاسة أعلاه.
المحدثة بالميلامين بواسطة بعض المعايير الفسلجية في إناث الجرذان إندان

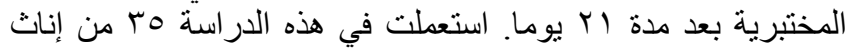

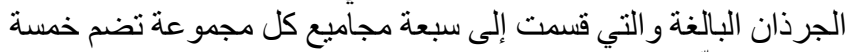

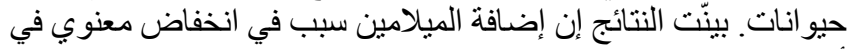

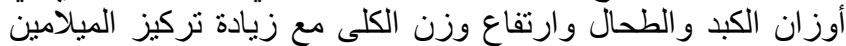

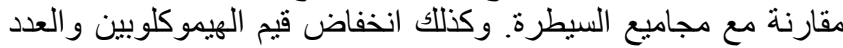
الكلي لكريات الدم الحمراء وكريات الدم البيضاء والئاء والخلايا اللمفية 